\title{
Is Learning a Wonder Weapon of Endogenous Economic Growth?*
}

\author{
Péter Mihályi
}

This essay attempts to refute the practicality of the main policy propositions of the book by Joseph Stiglitz and Bruce Greenwald (S\&G) entitled Creating a Learning Society. More specifically, it looks at the 700-page scholarly work from the perspective of countries struggling to catch up with the advanced Western countries. In the opinion of the author, S\&G use the term "learning" in such a broad sense that it becomes almost meaningless as an explanatory factor and/or an objectively verifiable indicator. Equally important, by using such a value-loaded, entirely positive term like "learning", S\&G create a misleading feeling in the readers: catching-up is easy (win-win). As history has shown, it is not easy. In the paper, the model of a lesser known Hungarian economist, Ferenc Jánossy (1914-1997), is presented as a more convincing explanation of endogenous economic growth.

Journal of Economic Literature (JEL) codes: E61, E71, F12, 126, I28

Keywords: Infant industry, learning-by-doing, labour productivity, endogenous growth, Washington consensus

\section{Introduction}

Personally, it makes me contented to see that thick theoretical books are now coming into fashion in economics once again. In the recent past, the first in the sequence was Daron Acemoglu and James A. Robinson's (2012) monograph - Why Nations Fail: The Origins of Power, Prosperity, and Poverty - with 529 pages. Two years later came the 703-page blockbuster work of Piketty (2014) and the joint work of Joseph E. Stiglitz and Bruce C. Greenwald (henceforth: S\&G) at 660 pages. One can, of course, make cynical estimates about the percentage of buyers of these books who really read them from cover-to-cover, but the sheer size of these works opens the possibility of a broad, deep discussion among those specialists who have

\footnotetext{
* The papers in this issue contain the views of the authors which are not necessarily the same as the official views of the Magyar Nemzeti Bank.

Péter Mihályi is a Professor at the Department of Macroeconomics at Corvinus University of Budapest and Visiting Professor of the Department of Economics and Business at the Central European University (Budapest), both in Hungary. E-mail: peter@mihalyi.com

The English manuscript was received on 25 April 2018.
}

DOI: http://doi.org/10.33893/FER.18.2.117139 
read the aforementioned books thoroughly. Social and economic issues are always multi-faceted. There is no such thing as a single-factor explanation. When complex and controversial issues, such as inequality in the case of Piketty or learning as the main driver of development in the case of $S \& G$ are analysed at this length, it opens up the possibility for specialists to verify or refute the authors' assertions from many angles (e.g. methodology, geographical validity, data reliability). Such a broad evaluation of new propositions is simply not feasible in the case of a journal article or conference paper, where only one assertion or hypothesis is made ("One idea, one paper") and there is simply no place to discuss the earlier, rival theories except of those published in the same or similar journals in the previous 3-4 years.

S\&G certainly meet the requirements of a prudently written monograph. Nearly all the 17 substantive chapters are enriched with appendices, in which they spell out the simply formulated, take-home message of the given chapter using a formal model. What is even more valuable (and rare), in the last part of the book (Chapters 18-22 and the Afterword) the giants of the economics profession, such as Philipe Aghion, Robert Solow and Kenneth J. Arrow express their opinion on the main tenets of the book itself, as they were formulated in the first, 2008 draft of the manuscript.

There is no doubt that S\&G set an extraordinarily ambitious task for themselves. In our reading, their aim was to come out with a landmark book and a persuading, unique policy doctrine on a par with the Communist Manifesto (1848) of the young Marx and Engels and The Stages of Economic Growth: A Non-communist Manifesto of W.W. Rostow (1960), an economic history account of the modern world economy. As the full title of S\&G's book indicates, the authors try to build a new conceptual model of growth, development and social progress.

Authoring a thick book like this comes with a trade-off. It takes a lot of time to read it. As S\&G explain, the book's main idea was born at a 2008 conference celebrating the work of K. J. Arrow in general and his "learning-by-doing" growth theory in particular. Those were very different times from the present ones, when trade wars are already being fought between the world's super powers. If the S\&G book had been drafted today, it would have been a very different book in many ways.

The rest of the paper is structured as follows. Section 2 summarises the main takehome policy recommendations of the S\&G book, and then Section 3 attempts to show the flaws in these ideas. Section 4 introduces an alternative model of knowledge dissemination based on the book of an internationally lesser known Hungarian economist, Ferenc Jánossy (1914-1997). The advantage of his model is that he interpreted learning as a qualitative change, as opposed to the "knowledge gap" approach used by S\&G which underscores the quantitative nature of the 
changes. Section 5 presents short summary and a prompt reaction to the 2018 Nobel prize awarded to Paul Romer for his endogenous growth model.

\section{Starting point of the S\&G hypothesis and its construction}

The concept of a "learning society" has been used in the scholarly literature for almost 50 years. ${ }^{1}$ Among international organisations, it was first embraced by the OECD (2000) as a key to a nation's economic development. The idea was subsequently taken further by the UNESCO, stating that education should extend beyond formal learning (in schools, universities, etc.) and continue until the end of life ("lifelong learning").

But this is not the point where $S \& G$ start the presentation of their hypothesis. They start with the rejection of the mainstream, neoclassical growth model, the CobbDouglas production function, the famous $Y=A\left(K^{\alpha} L^{1-\alpha}\right)$ equation, the Solow model and the Golden Rule of Edmund Phelps, because this family of models assumes that technological change is an exogenous factor in the model. This criticism, as $S \& G$ readily acknowledge many times in the book, is not original. It is derived from Arrow (1962), where the concept of learning by doing, as the endogenous driver of labour productivity growth was first introduced. ${ }^{2}$ Let us recall that the idea of endogenous growth itself can be traced back to the so-called Verdoorn law (after the Dutch economist P. J. Verdoorn) and through him back to Adam Smith. As is well known, it was the great Scottish philosopher who first realised that the unstoppable rise of labour productivity is primarily the consequence of the division of labour which in turn leads to "the increase of dexterity in every particular workman" as a by-product of the rising volume of production. When a cobbler makes a boot or the hairdresser cuts a client's hair in practicing his profession, he himself becomes better and more productive all the time. This is all true, even if the cobbler or the hairdresser does not invent anything new, but simply applies and practices the know-how invented and introduced by others. Thus, rising productivity is achieved through practice, self-perfection and minor innovations, without adding workers or investing significant amounts of capital. This line of thinking was taken further by Verdoorn (1949), who found statistical evidence that in the long run macroeconomic productivity grows proportionally to the square root of output.

According to $S \& G$, the secret of technical progress is not innovation, but the dissemination of innovation embodied in the learning-by-doing process (p. 490).

\footnotetext{
${ }^{1}$ See e.g. Hutchins (1970), Schön (1973), Husén (1986) and Hughes - Tight (1995) among the English language works published before the millennium.

2 Arrow's specific microeconomic example to justify the concept of learning-by-doing was borrowed from a 1936 paper published in an aeronautical journal, according to which the labour hours required to build airplane frames declined in reverse proportion to the third root of the number of frames built. As the cited author - Wright (1936) - explained in the paper, his cost estimates were based on his own personal work experience in the 1920 s.
} 
And indeed, if we take a look at the countries in the world, it is not difficult to observe that productivity differences within one country and/or within a single industry of the same country are quite considerable. Lewis's (2004) empirical study, based on the collective effort of the research staff of McKinsey Global Institute, is full of such examples. At the end of the 1990s, labour productivity in the Japanese retail trade sector was not higher than one half of the comparable US figure, while the successful Japanese car manufacturing firms - such as Toyota - surpassed in labour productivity their US competitors by a margin of 30 per cent. Labour productivity in housing construction varied even more. ${ }^{3}$

As a generalisation of the learning-by-doing theory, the $S \& G$ hypothesis is built on four new propositions:

(i) Growth is based on innovation, which in turn is based on learning. Both concepts are more important than allocative efficiency.

(ii) The presumption that all firms are efficient is false; the majority of firms always operate below the efficiency frontiers, whether in the United States or elsewhere.

(iii) Knowledge is quantifiable. The "knowledge gap" between the potential maximum and the actual average within a country or within a given industry is in itself a source of rent.

(iv) If the knowledge gap is persistent, countries can be trapped in a low-level equilibrium (low rate of productivity growth) even over the medium or long term. ${ }^{4}$

From here, the thinking of S\&G makes a turn that takes them beyond Myrdal (1957) and Kaldor (1966), who in the 1960s were already inclined to support state intervention as a part of macroeconomic demand management in the allocation of resources. ${ }^{5}$ But why should the state control the knowledge dissemination process from the supply side (as opposed to the Keynesian demand-side explanation)? According to S\&G, globalisation and within this the growing gap between social and individual returns is the most important impediment to worldwide, lasting and equitable growth. Knowledge is a public good and in the absence of government

\footnotetext{
${ }^{3}$ The book drew on extensive microeconomic studies of 13 countries over 12 years conducted by the Institute staff and invited world-class university professors, such as Robert Solow himself. See also fn. 9.

${ }^{4}$ For the first authentic formulation of these hypotheses, see Greenwald - Stiglitz (2006).

${ }^{5}$ On Kaldor's views in this regard, see Mihályi (2017) and Thirlwall (2017).
} 
intervention it is undersupplied by utility maximising firms and/or individuals. ${ }^{6}$ Unlimited free trade, the cross-border flow of capital and labour, the mechanism of freely floating exchange rates, the liberalisation of financial markets ${ }^{7}$ and the harsh protection of intellectual property rights (essentially the entire list of the Washington consensus, Williamson, 1990, 2008) are all problematic, because in the less developed economies - i.e. practically in all countries, except the US the overwhelming American productivity superiority prevents the local engineers, workers and business managers from learning and innovating. Under such a regime, conducting research is bound to fail businesswise. But without continuous learning and innovation, there is no opportunity to grow and develop. From the point of view of the developing countries - or using S\&G's terms: infant industries and infant economies - it is more promising to restrict competition and protect the entire home economy rather than entering into open competition with the more advanced economies.

According to Stiglitz and Greenwald, infant economies have two good reasons to protect their internal markets and support the national companies' learning and research possibilities: (i) the countries and the domestic firms learn directly from the production process as the learning-by-doing theory suggests; and (ii) the newly acquired knowledge always has significant, dynamic spill-over effects (or positive externalities). S\&G mention several examples, such as technological innovations in the manufacturing sector where a good idea of one firm can be applied later by other firms of another industry, or organisational innovations, such as the "just-intime" inventory management technique which can be applied across industries, once the necessary organisational skills and disciplines are learned by a relatively large pool of managers (p. 65).

If we return to the previously mentioned example of the cobbler, the problem is that once it was found out how to produce good quality, inexpensive boots in the US, firms in other countries will never be able to compete with the industry-leader US cobbler. According to the S\&G hypothesis, this is a major problem not because all other countries will find it more economical to import boots from the US, but because the infant economies will never learn how to make boots. Furthermore, once a boot factory in a developing country starts its operation despite the poor chances of success, there is a high likelihood that it will lose out in free competition and go bankrupt. Then the already acquired "new knowledge" will be wasted ( $p$.

\footnotetext{
${ }^{6}$ Although S\&G fail to mention, there is nothing new in this proposition either. Enhancing the Marshallian concept of externalities, Marshall's favourite disciple, Arthur Pigou (1920) stated exactly the same: "selfinterest will not (...) tend to make the national dividend a maximum" (Part II, Chapter IX). In the original Arrow paper, the same proposition is made as well. The competitive solution is different from the societal optimum solution, because "learning means that an act of investment benefits future investors, but this benefit is not paid for by the market" (op. cit. p. 168).

${ }^{7}$ Exposing their criticism over this issue, S\&G go quite far in the direction of populism, when they refer to "speculative businesses" and conclude that "in certain cases it is more efficient, if the state implements the allocation of capital investment itself" (op. cit. pp. 410-411).
} 
491) and the spill-over effects will cease driving the other segments of the economy forward. According to S\&G, their theory is valid historically as well. "[T]he fact that some countries and firms have "learned how to learn" helps explain why the last two centuries have seen such remarkable increases in standards of living, in comparison to the millennia that preceded them, which were marked by stagnation" (p. 373). In short: the secret of development is learning and learning to learn. ${ }^{8}$

\section{Challenging the S\&G theory}

The S\&G hypothesis is not convincing at all and the solicited commentators on the original 2008 draft (Aghion, Solow and Arrow himself) did not hide very much their own reservations either. In our opinion, Stiglitz and Greenwald pretended as if they did not know...

1.... that the essence of the capitalist system is the rivalry. There are always winners and losers in a competitive environment (Lavoie 1985). Only in the world of Utopia can one think of countries enjoying the same level of economic development and the closure of the knowledge gap.

2. ... that market competition is the strongest driver of innovation, even if there are well-known situations when limited competition actually hampers innovation (e.g. the rise of monopolies).

3. ... the variation of productivity among firms operating on the same market is not caused by a failure in learning. It is the result of better management, ${ }^{9}$ the power of increasing return to scale and the natural monopoly situations arising from it. In other cases, better performance and higher productivity are simply a matter of luck. It doesn't make much sense to say that Facebook is successful because its managers "learned how to learn", while Compaq, the once renowned computer manufacturer disappeared from the world markets because its business leaders were bad "pupils". ${ }^{10}$

4. ... that if a Chinese product outcompetes an American or a European producer, the reason is not that the Chinese workers are cleverer or have learned more. It is usually because Chinese wages are still so much lower. ${ }^{11}$

\footnotetext{
${ }^{8}$ The expression of "learning to learn" was originally developed in Stiglitz (1987).

${ }^{9}$ This point was actually raised in the contribution of Robert Solow in Chapter 21. He directly referred to the empirical findings of Lewis (2004), in which he was one of the main research contributors. The key finding of the research was that the lower quality of management did not have much to do with learning, knowledge or competence. The cross-country comparisons showed that it was caused "by the weakness of competitive pressure, and the most important obstacle to competitive pressure was formal or informal protection. Firms and industries exposed to competition from best practice were driven toward best practice" (op. cit. pp 501-502).

10 In fact, the company disappeared after it signed a merger agreement with Hewlett-Packard in 2002.

11 I am grateful to Michael Joffe for this crucially important completion of my argumentation.
} 
5. ... the 75,000 employees who lose their jobs on every working day in the American economy are not bad "learners" either. They get fired because the structure of the economy is constantly changing. Certain industries created new jobs for decades (e.g. retail trade, publishing, etc.), but after some fundamental shifts in technology, the very same industries started to shed labour. ${ }^{12}$

6. ... that rent-seeking and corruption are more important snags in the developing countries than in the advanced ones. Therefore, centrally determined industrial policies carry with them an intrinsic risk. If governments assume the power to select the winners, the industries and firms that "merit" protection, the risk of state capturing might arise, and in this way industrial policies become the hotbed of corruption. ${ }^{13}$

Several contradictions arise from the fact that the two authors of the Learning Society are Americans and that therefore the book was chiefly addressed to the American readership. They tried to phrase their ideas in a way that is understandable and attractive for Americans. For example, it is a widely held opinion that the American educational system is disgracefully feeble and, therefore, emphasising the importance of learning is a popular proposition for every segment of American society. The upper middle class and the middle class are happy to read about this because these elites are convinced that they merited their relatively high social positions through successful education (Reeves 2017). The lower level classes also like to be open to the importance of education, because they expect the government to spend more on the education of their children.

Who is losing in free trade? At this point, some readers of the present paper might start to protest and raise two objections. First, it has been argued for more than 200 years by scholars of the economics profession that free trade is not desirable for developing countries and new ("infant") industries. The most important example was the case of the United States of America. Alexander Hamilton, one of the founding fathers, who served his newly born country as Secretary of the Treasury between 1789 and 1795, became renowned as an opponent of free trade and as a supporter of protectionism. It is also common knowledge that Hamilton's views influenced the German Friedrich List (1841), who became the main proponent of economic protectionism on the European continent two generations later. Second, speaking for protectionism and against free trade means something very different today, when the United States - as the most developed Western country - complains about the consequences of free trade on its labour markets, than it did before the trade war started between China and the United States.

\footnotetext{
${ }^{12}$ Krugman (2016)

${ }^{13}$ This argument, which is probably trivial for readers in the post-communist countries, was mentioned in the contribution of Philippe Aghion (p. 496). Together with Iván Szelényi, the present author came to similar conclusions in Mihályi - Szelényi (2017).
} 
Piketty's voluminous book, already mentioned above, was a totally unexpected and unparalleled commercial success. In two years more than 2.1 million copies were sold in French, English, German, Chinese and Spanish. For many reasons, $S \& G$ is unlikely to come close to this achievement. Among the reasons, I presume, the protectionist trade rhetoric of the current US administration is by far the most important. Any idea that so closely resembles the official US government position is bound to be rejected by the academic circles in the United States and the prestigious European university departments as well. It is widely known that there was a historical precedent, when protectionist legislation was enacted by the US Congress and signed into law by a president, but the consensus view today is that the so-called Smoot-Hawley Tariff Act of 1930 was - also according to Arrow - "a very destructive policy" (p. 508). ${ }^{14}$

Against the backdrop of such history and the noisy trade protectionism of many Republican-leaning congressmen and congresswomen, everything that was proposed by Stiglitz and Greenwald in 2014 sounds totally different today. While the book's main idea, that learning can be a wonder weapon in the hands of enlightened, good-willing policy-makers, will continue to attract many supporters, the present academic environment will remain unsupportive of the policy proposals emanating from S\&G's interpretation of the "learning by doing" metaphor. As long as the ongoing trade negotiations are not completed, S\&G's suggestions pointing in the same direction will be hardly heard.

It is inconceivable that the two authors did not take into consideration that the asymmetric limitation of free trade and/or administrative manipulation of exchange rates are not real options for infant economies. They don't have enough power. It is very difficult to speak openly like this: "We would like to export freely, but we restrict imports. We will keep the value of our currency low, but our trade partners should allow their currency to fluctuate freely." Using double standards can be one element in the toolbox of a powerful country. As recent examples show, the US was able to put pressure on other countries to open their market to US goods, while the

\footnotetext{
${ }^{14}$ The full, official title of the Act was already expressive: "An Act to provide revenue, to regulate commerce with foreign countries, to encourage the industries of the United States, to protect American labor, and for other purposes." When it was still under debate in Congress, a petition was signed by 1,028 economists in the US asking President Hoover to veto the legislation. The legendary automobile executive Henry Ford spent an evening at the White House trying to convince Hoover to veto the bill, calling it "an economic stupidity." J. P. Morgan's chief executive Thomas W. Lamont said he "almost went down on [his] knees to beg Herbert Hoover to veto the asinine Hawley-Smoot tariff." Initially, Hoover himself opposed the bill and called it "vicious, extortionate, and obnoxious", but eventually he yielded to influence from his own party and signed the bill. The new tariff imposed an effective tax rate of 60 per cent on more than 3,200 products and materials imported into the United States, quadrupling previous tariff rates on individual items, and thus raised the average tariff rate to 19.2 per cent. As was feared, Canada and other countries raised their own tariffs in retaliation after the bill had become law. Unemployment was at 8 per cent in 1930 when the Smoot-Hawley tariff was passed, but the new law failed to lower it. The rate jumped to 16 per cent in 1931, and 25 per cent in 1932-33.
} 
US markets remained closed for the partner country. But this is not a viable strategy for converging countries, except for the very large ones such as China or India. ${ }^{15}$

To whom is the book's message addressed? To whom do the authors direct their policy recommendations? To the poorest countries of Africa, the 10 new Member States of the European Union, to Russia or China, or to Greece or Italy, as the laggard countries in the EU? In the book, there is no answer to this critically important question. What is even more troublesome, the authors close their book by saying that industrial policies and government interventions in trade are desirable and may even be a permanent part of economic policy in the most advanced countries and not just in the early part of the convergence period of an ambitious infant economy (p. 474).

Learning has several meanings in the book. As we noted already, much of what S\&G call learning is partly or entirely something else. There are at least five different meanings of "learning" in the book.

1. Often the term's true meaning in the given context is adjustment (p. 375). Firms always try to adjust to the changing market conditions, sometimes successfully, other times unsuccessfully. Behind the failures the retrospective analysis usually identifies managerial mistakes, bad judgment or slow reaction.

2. Industrialisation in lagging, catching-up countries is always based on emulation. In these economies, improved competitiveness at the level of firms means the adoption of existing technologies, and usually not the latest ones. If this is followed by innovation, this innovation is incremental and of small significance. This was the "secret" of the successful industrialisation of Japan, the Soviet Union, and South Korea. Other authors rightly use the term catching-up growth to characterise the nature of this type of development. By contrast, cutting-edge growth is observable only in the most advanced countries. ${ }^{16}$ Confounding the two types of progression and the two types of learning processes behind them is utterly misleading.

3. Few growth specialists or economic historians would question the importance of acquiring basic cognitive skills, like reading, writing, arithmetic, etc. There is a huge literature asserting that economic development is correlated with formal education (schooling), especially with the advancement of primary education.

${ }^{15}$ Robert Solow pointed out this contradiction, and - in an extremely polite way - made a devastating counterargument. It is true that for an infant economy it is of vital importance to direct its products toward export markets in order to exploit the advantages arising from scale economies. Exporting is also very important to maintain and improve the quality of its products and services under the pressure of the high requirements of the foreign buyers. At the same time, however, it follows from the S\&G hypothesis that the infant country should protect its own domestic markets from foreign competitors. One can imagine tolerance for the protection of an infant industry here and another there, but an overarching protection for an entire infant economy would be a harder sell (op. cit. p.501).

${ }^{16}$ See Joffe (2017). With the same meaning as cutting-edge growth, Jones (2015) introduced the term frontiergrowth. 
4. Since Max Weber's hypothesis on the contribution of the Protestant values to growth, there has been a broad agreement that non-cognitive (cultural or soft) skills are also indispensable for growth. Sometimes these skills are part and parcel of the local, traditional culture (e.g. Protestant ethic, Confucianism); in other cases, these skills need to be "imported" and disseminated by the educational system, religious organisations, the media, etc. The dissemination of English as a foreign language and Anglo-Saxon cultural values is a good recent example in Eastern Europe. The modernisation of Russia under Peter the Great (1696-1725) and Japan during the Meiji period (1868-1912) worked with similar policy tools. Such implantations are almost impossible to carry out effectively without some kind of government commitment, although today much of it happens through the unstoppable use of the internet and mobile phone applications, even if the incumbent governments don't like it or try to stop it. A recent bad example in this regard is the decision of the Iranian leadership to ban the teaching of English in all primary schools. ${ }^{17}$

5. Admittedly, the US has been the most advanced and most productive economy for about a century, and its advantage has only increased vis-à-vis Western Europe since the onset of the international financial crisis of 2008. But how can the US economy be so effective in spite of the allegedly poor quality of its educational system? In our opinion, the answer is simple. The tens of millions working in the trade and service sector don't need to learn how to do business in school. They bring this knowledge from home. Americans have been good entrepreneurs since the foundation of the Republic, and there is a constant supply of potential entrepreneurs through immigration.

The importance of resistance to learning. The authors correctly point out more than one time in the book that certain conservative societies are purposely built on the strategy of no-change (p. 96). But they fail to draw the conclusion from this, namely that in such cases what is missing is not "learning" or "the capacity to learn", but those specific values that are required to catch up with the more advanced countries. In more difficult cases, the majority of people in such conservative countries are honestly and deeply convinced that it is in their country's interest to defend the "old" values.

Finally, an author from a post-socialist economy can only regret that S\&G do not even mention the bitter experiences of the large and small former socialist countries, such as the Soviet Union or Hungary, and the military dictatorships in Latin America that in many ways were similar to the planned economies. Dozens of such countries pursued protectionist policies for decades in the $20^{\text {th }}$ century. But

${ }^{17}$ The Guardian, 7 January, 2018. 
their overall growth performance was dismal. These countries failed to catch up with their international competitors as long as they pursued such policies.

In a certain sense, this is understandable. Professor Stiglitz and Greenwald do not have personal experience with such regimes and, therefore, do not have a gut feel for how centralised, autocratic regimes function. But they should know from the literature that there are few good examples proving that state-initiated trade restrictions, investment policies, and industrial research - which are all important parts of the "learning society" model - lead to the hoped-for results, to a sustainable increase in competitiveness and catching-up in productivity levels. Only the case of Japan (between 1945 and 1990), South Korea (1978-2010) and Taiwan (1960-1990) can be cited as convincing examples. If in the case of China, state-supported industrial research brings significant and sustainable returns to the country in the future (which is far from certain), this is probably due to the gigantic size of its economy. ${ }^{18}$

\section{A better theory of "learning by doing"}

Learning is a qualitative change. Even among Hungarian economists of the young generation, only a few read and remember the works of Ferenc Jánossy (19141997), a Hungarian economist of great originality. ${ }^{19}$ This is a pity because much of S\&G sounds very similar to Jánossy's thoughts developed during the 1960 s. In our opinion, Jánossy put forward a more convincing endogenous growth theory than the S\&G concept.

The central assumption of this theory is that over the long run the productive potential of an economy is determined by the size and qualification structure of the labour force only. Technically speaking, the slope of the long-run potential growth path is determined by the rate of accumulation in labour qualifications and is thus unaffected by the investment rate. In the short run, however, actual output is limited by the workplace structure of the economy, i.e. the capital stock and its technological composition. In crisis-free economic development, the complementary factors of production tend to accumulate in harmony, so that the employment structure of the economy reflects the qualification structure of the labour force. However, in the immediate aftermath of a war or a major depression, a large gap between actual and potential output can open up due to a severe distortion in factor proportions. This phenomenon is termed "structural incongruence" and is

\footnotetext{
${ }^{18}$ According to the latest available data, China's total R\&D in 2013 was equal to the money the United States spent in 2005 (Veuglers 2017).

${ }^{19}$ Ferenc Jánossy grew up in Germany and worked and studied engineering in the Soviet Union between 1933-1946 before returning to his native Hungary. German was his first language; therefore everything he wrote in German was subsequently translated into Hungarian. His most important book, The End of the Economic Miracle. Appearance and Reality in Economic Development was simultaneously published in German and Hungarian in 1966. The English translation, used in the present paper, appeared in 1971.
} 
assumed to result from the depletion of physical capital, especially machinery, as a consequence of wartime destruction and/or depressed investment activity. This structural incongruence constitutes an extraordinary growth potential. Initially, due to the low capital-labour ratio, returns on capital are very high, inducing exceptional rates of investment and, consequently, accelerated capital accumulation. In other words, during the reconstruction period, there are no labour-supply constraints on capital formation. Once the economy returns to its long-run potential growth path, the miracle ends. Further expansion must rely exclusively on improvement of the qualification structure of labour, since the complementary workplace structure of the economy can no longer develop faster. ${ }^{20}$

In this complex model, Jánossy interpreted learning - i.e. the improvement of the qualification structure of the labour force - as a qualitative change rather than a quantitative process: “man's individual knowledge today is not necessarily greater than yesterday's, but mainly of a different kind" (Jánossy 1971: p. 205). This is very much different from Arrow's starting point ("knowledge is growing in time"21) which has been taken over uncritically by S\&G. If, however, learning means a qualitative change, there is no such thing as a "knowledge gap" that separates infant economies from the more developed countries (as S\&G claim on p. 481). Every child who grew up on the enchanting Indian stories of James F. Cooper or Karl May knows that the life of Native Americans required all sorts of knowledge (horseriding, hunting, making fire, shooting arrows, etc.) which were necessary to survive in that environment. Their knowledge, of course, was immeasurably different from the knowledge of modern American farmers growing wheat in the state of lowa, or a banker working on Wall Street today. But horse-riding is not a must anymore.

The concept of "learning by doing" was identified by Jánossy independently from Arrow, and his metaphor (learning from the machine) was more illuminating than that of Arrow. As Jánossy wrote "cutting can only be learned at a lathe, crushing at a milling machine, and driving at the wheel of the car. (...) This transfer of knowledge through the means of production is of particular interest (...) because this is precisely what causes the misleading impression that perfection of machinery is the primary factor of economic development" (op. cit. p. 209). Due to this important link, there is no real substitution between capital (C) and labour (L). Both of them are needed - simultaneously at a given point of historical time and in more or less fixed proportions. ${ }^{22}$

${ }^{20}$ For a detailed, English language summary of Jánossy's model and fresh research in the spirit of Jánossy, see Tarján (2002) and Vonyó (2008).

${ }^{21}$ See Arrow's clear statement in the first paragraph of his 1962 paper (op. cit. p. 155). Author's emphasis (P.M.).

22 This is very different from Arrow's original approach, where the cumulative production of capital goods is used as a proxy for workers' experience - i.e. for learning. 
Forced industrialisation is risky. In several of his writings, Jánossy discussed the ways and means how these fixed proportions were often purposely distorted by government policies. One important example is when state-controlled, forced industrialisation leads to loss-making investments and then the government has no choice other than to impose limits on other market participants to protect the newly created factories. This may make sense, concludes Jánossy similarly to $S \& G$, if and when the loss-making investment significantly helps the formation of the working force in the enterprise concerned. The example of the Soviet industrialisation drive in the 1930s proves that such policies are sustainable for quite some time. But there are two uncomfortable by-products of policies based on the presumption that allocative efficiency doesn't count. Firstly, to maintain such a system, the state needs a large and brutal state apparatus, because these loss-making investments are financed to the detriment of consumers. With the benefit of hindsight, it is very likely that the development of Russia would have been faster and much less murderous than it was, if the market system had been maintained all along the 70 years of socialist planning. Second, the forced investment drive - at least in the Soviet or the Chinese cases - led to slow growth in consumption, which in turn slowed the "learning" of the labour force. Widespread knowledge of driving supposes private ownership of passenger cars, clean working hands require the availability of bathrooms at home, the knowledge of foreign languages requires mass tourism, etc.

Jánossy, who spent many years in the Hungarian Planning Office, warned his contemporary socialist planners not to try to accelerate economic growth through radically increased research and development expenditures (R\&D) either. Although it is not easy to comprehend on first hearing, innovation, as the output of research, does not generate welfare directly. Innovation is merely a "recipe" that shows how the structure of production needs to be modified in order to increase the productivity of labour (op. cit. p. 117). Whether the conditions of implementing the necessary restructuring of production are present or not in a given country and a given industry, depends on the quality of the labour force at large, and not on the quality of the researchers. It doesn't help if the R\&D activity runs much ahead of the quality of the labour force. If this happens, it leads only to massive societal waste.

As shown above, the broader meaning of learning in the $S \& G$ concept included emulation, the copying of technologies of the more advanced countries. There is nothing wrong with this. Although in theory, the possibility of a revolutionary innovation being born in an infant economy cannot be excluded, the experience of the past two centuries has showed that all pioneering innovations came from the most advanced countries such as Britain, Germany, and the US. János Kornai (2014) compiled a list of 111 innovations of great significance and proved that indeed only the most advanced countries were capable of converting inventions to innovation 
and organising the large-scale manufacturing of the new product in a commercially viable way (op. cit. pp. 5-18). There are few exceptions to this rule. The inventor of the ballpoint pen lived in Argentina, Nescafe is a Swiss product, and the software behind Skype was developed in Estonia, but none of these innovations had a major macroeconomic impact on the countries where these exceptional technological attainments were achieved.

Before anybody falls in love with the "Learning Society" hypothesis, it is worth recalling the warning of Jánossy (1969) who introduced the concept of "quasidevelopment". This is directly linked to emulation or copying. As he argued 50 years ago, when a country tries to accelerate economic growth in general and the development of manufacturing industry with protectionist trade policies and artificial manipulation of the exchange rate, etc., there is a danger that the emulation will be successful only in a statistical sense. The volume of production will increase, but the quality of goods coming off the conveyor belts of the newly created factories will be hopelessly inferior to the products of the advanced market economies. Many socialist countries went through this bitter experience. Perhaps the most telling illustration is the fate of the Soviet Lada passenger cars produced during the 1970s and 1980s, originally copied from a 1966 model of the Italian car manufacturer Fiat. Millions of such cars were manufactured, but they were outmoded from Day One onwards, and the factory made financial losses on the Western exports of these cars.

Aggressive spending on schooling does not guarantee success either. It follows from Jánossy's endogenous growth concept that growth also cannot be accelerated by the forced expansion of schooling.

- Let us illustrate this point first with present-day pair-wise comparisons. Take Poland and Germany. According to standardised OECD data, the share of persons in the labour force with a tertiary education degree is the same in both countries (28 per cent), while productivity ${ }^{23}$ is more than 2.1 times as high in Germany. We can take another, even more shocking, example. In the 25-64 age group, 54 per cent of the Russian workers had some tertiary education, which is much higher than the corresponding American, Japanese or Israeli figures (all between 45-50 per cent), let alone the comparable Danish figure (37 per cent). Regarding productivity, however, the American level is 2.5 times as high as in Russia.

- Similar differences can be identified when the least educated population is compared (primary education). The share of Hungarians in the labour force with no more than 8 years spent in school is just 1 per cent, while in Portugal this

${ }^{23}$ Measured as output per hour worked in international US dollars (converted to 2016 price level with updated 2011 PPPs). 
indicator stands at 32 per cent. From this strikingly large difference, one would assume that the Hungarian economy must display higher productivity levels. However, the contrary is the case: output per hour worked is 10 per cent higher in Portugal than in Hungary. ${ }^{24}$ It is worthwhile to cite old cross-country comparisons as well. In 1910, the percentage of illiterates in Hungary amounted to 15 per cent and the country's GDP was estimated by Maddison at 2,000 \$/head. ${ }^{25}$ By contrast, in Italy and Belgium, where the illiteracy rates were 38 and 25 per cent, respectively, the GDP/head figures were 2,332 and 4,064 dollars - i.e. significantly higher than in Hungary.

- Cross-country studies equipped with rigorous econometric tools also lead to similar conclusions. In Pritchett (2006), the lack of econometric evidence for the quantitative "knowledge gap" is explained by the fact that over the last 50 years schooling at all levels (from primary to tertiary) has expanded massively on all continents, while there has been a historical and continued divergence in output per capita. Hence, the cross-national dispersion of schooling per worker and the dispersion of output per head have moved sharply in opposite directions.

Thus, the implication that the level and growth of aggregate schooling per worker will do, at best, a modest amount to explain the growth of output per worker only confirms Jánossy's assertion born in the 1960s.

As another Hungarian economist - Polónyi (2010) - already noted, this "overeducation" is not a unique Hungarian phenomenon. It holds for all the post-socialist countries that the population's formal educational level is higher than in market economy countries with similar levels of economic development. Quite clearly, this over-education drive was - to a very great extent - driven by the absence of tuition fees during the decades of socialism. As Jánossy (1969) and Holló (1974) who worked together showed, the extensive growth strategy in general and in the educational sector, in particular, led to quasi-development and over-education, or waste - if we allow ourselves to use such a harsh term. Later research upheld this speculative finding. Covering more than 60 countries with comparable PISA-test results, a study by the consulting company, McKinsey (2010:14-15) found that in low- and middle-income countries "systems with similar education spending have widely varying levels of performance - until the USD 6,000 spend per student (PPP) mark is reached - system performance spans the full spectrum of poor, fair, good, and great". Better schools do not necessarily lead to more growth (Hanushek Woessmann 2012).

\footnotetext{
${ }^{24}$ The source of education and productivity data are https://stats.oecd.org/Index.aspx?DataSetCode=EAG NEAC (downloaded on 30 August 2017) and The Conference Board (2017), respectively. All data refer to 2015.

${ }^{25} \mathrm{GDP} /$ head data in constant 1990 USD.
} 
Resistance to change/learning. At this point, it is worthwhile to return to one of the shortcomings of the $S \& G$ hypothesis which was mentioned above: namely, that it does not pay sufficient attention to the natural inertia of societies and the conscious resistance to change. By using such a value-loaded, entirely positive term like "learning", Stiglitz and Greenwald create a misleading feeling in their readers: catching up is easy. In reality, the transition has always been difficult from low to middle or from middle to upper-income and very few countries have succeeded in it. ${ }^{26}$ In the last 20 years, South Korea was the only large country in the world that managed to pass the second hurdle.

Jánossy showed with a simple argument that rapid economic progress is not easy at all, because people, for good reasons from their perspective, resist. "For if no great resistance would stand in the way of diffusion of new achievements and of greater labour productivity, there would be no people left who carry drinking water home in earthen vessels on their heads from the well, no nomad tents, and even no steam locomotives, the last specimens of which would already stand in museums next to waterwheels and handlooms" (op. cit. p.135). Often religious norms are the main obstacle, such as the strict interpretation of Islamic sharia law in some countries according to which girls should not be allowed to go to school. ${ }^{27}$ The traditional forms of Hinduism have a similar negative impact on women's education and employment. In other cases, as the authors of the third thick book, Acemoglu and Robinson, convincingly demonstrated, the resistance comes from a small group of people or a minority group within the country controlling all political institutions and excluding others from decision-making, ownership rights, fair competition, etc. This, in turn, may lead to counter-resistance, strikes, uprisings and civil wars, which then throw countries back in development by decades. A few hundred years ago, the resistance to change and to new narratives was difficult in Europe too. Scholars at the turn of the $15^{\text {th }}$ and $16^{\text {th }}$ century often risked their own lives when they criticised the canonised truths of Greek and Latin authors, dead already for many hundreds of years.

Convergence is difficult, because the pioneers learn too. With the introduction of the "knowledge gap" concept, the S\&G hypothesis creates a deceitful image about the future chances of infant economies to catch up with the most advanced

\footnotetext{
${ }^{26}$ Using the World Bank's categorisation - low-, middle and upper-income countries - and more recent data for a large number of countries Cox (2017) paper is a convincing illustration of this statement.

${ }^{27}$ A 2017 Pew Research Center survey in 39 countries asked Muslims whether they want sharia law, a legal code based on the Quran and other Islamic scripture, to be the official law of the land in their country. Responses to this question varied widely. Nearly all Muslims in Afghanistan (99 per cent) and most in Iraq (91 per cent) and Pakistan (84 per cent) support sharia law as official law. But in other countries, especially in Eastern Europe and Central Asia - including Turkey (12 per cent), Kazakhstan (10 per cent) and Azerbaijan (8 per cent) - relatively few favour the implementation of sharia law. The variation in Africa is also considerable: 86 per cent in Niger, but only 37 per cent in Tanzania. http://www.pewresearch.org/ fact-tank/2017/08/09/muslims-and-islam-key-findings-in-the-u-s-and-around-the-world/, downloaded on 1 September 2017.
} 
countries. It is enough that well-meaning policy-makers support learning and the spread of innovation in all possible ways. By contrast, Jánossy presented a very simple illustration that shows that - beyond the problem of resistance, analysed already above - the horrendous difficulty in catching up with the most advanced countries lies in the fact that the most productive economies are usually capable of improving their performance all the time, and there is no intrinsic impediment blocking them from innovating further.

In the Anglo-Saxon world, this phenomenon is known as the Red Queen Hypothesis, which is an often used metaphor in everyday life, in economics, in the theory of arms race, in evolutionary biology, etc. The Red Queen is a fictional character in Lewis Carroll's (1865) fantasy novella, Through the Looking-Glass. Talking to the realworld hero of the book, Alice, the Red Queen described her empire as a system, in which "It takes all the running you can do, to keep in the same place." In narrow, economic terms, this is the description of competition: if your competitors are moving ahead, you have to move as fast, not to lose ground. In broader evolutionary terms (Valen 1973), the message is: "For an evolutionary system, continuing development is needed just in order to maintain its fitness relative to the systems it is co-evolving with."

The following model directly taken over from Jánossy's book (op. cit. pp. 128-131) illustrates the connection between the diffusion of innovations and the rise of productivity in time and space. Let us assume that six shipwrecked sailors $-A, B$, $C, D, E$ and $F-$ go ashore on a Monday and start to catch turtles as the only source of food on an uninhabited island. After one day of hard work, each of them returns with 10 turtles. Then sailor $A$ racks his brain overnight and comes up with a trick, a kind of a turtle trap, with which he succeeds in doubling his catch on Tuesday. He catches 20 turtles instead of 10, while the other five sailors achieve only the yield of the previous day. After that, the innovation begins to spread. On Wednesday the trap is already used by sailor $B$, and on Thursday by sailors $A, B$ and $C$ as well. On Friday, $A$ succeeds in perfecting his method further, and thus catches 30 turtles, while $B, C$ and $D$-still using Tuesday's innovation - continue to get 20 each, while $E$ and $F$, still using their hands only - catch 10 each. The improved method finds acceptance too and is adopted by $B$ on Saturday, while all the others remain content with Tuesday's innovation, except for the most backward among them, $F$, who still hunts turtles without any tool. Table 1 below shows the "catch" for each sailor and each day. 


\section{Table 1}

The spread of innovation in catching turtle in the Jánossy model

\begin{tabular}{c|c|c|c|c|c|c|} 
Sailor & Monday & Tuesday & Wednesday & Thursday & Friday & Saturday \\
\hline$A$ & 10 & 20 & 20 & 20 & 30 & 30 \\
\hline$B$ & 10 & 10 & 20 & 20 & 20 & 30 \\
\hline$C$ & 10 & 10 & 10 & 20 & 20 & 20 \\
\hline$D$ & 10 & 10 & 10 & 10 & 20 & 20 \\
\hline$E$ & 10 & 10 & 10 & 10 & 10 & 20 \\
\hline$F$ & 10 & 10 & 10 & 10 & 10 & 10 \\
\hline
\end{tabular}

Source: Jánossy (1971) p. 129.

In order to show the course of the first and the second innovation - increasing the daily catch from 10 to 20 and then from 20 to 30 - the data in the table are presented in graphic form (Figure 1) too. The figure is a representation, in a general sense, of productivity as a function of time and place.

\section{Figure 1}

Transmission of the best practice, as an illustration of the diffusion process in general

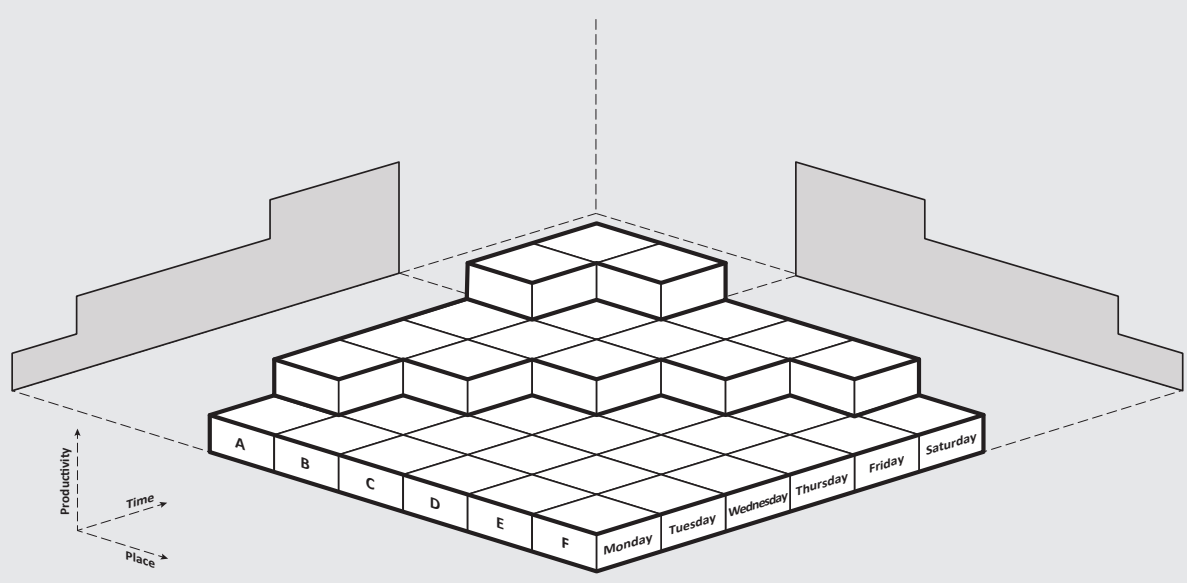

Source: Jánossy (1971) p. 129.

The three-dimensional figure has the advantage of showing both the increase of productivity in the course of time and the growing variation of productivity for each day of the week (non-existent on Monday, quite significant on Saturday). These two cross sections of time and sailors are shown as projected silhouettes. The third projection, an aerial view shows the diffusion process itself - i.e. how fast the steps of productivity created by the inventions of sailor $A$ were diffused. The measure of diffusion at a given time is the number of sailors who have already adopted the 
innovation. In this example, the speed of diffusion is one worker per day. Let us now leap from the six sailors to the entire population of the globe, and from the "developments" of one week to developments of several centuries, while we stay in the one-product (turtles-only) world.

Let each sailor correspond to a country, his labour productivity to the average productivity in that country, and the week on the uninhabited island to world economic history over the past 200 years. The increase in productivity of one country forms a cross-section through time - this is the per capita growth of national income (or GDP). On the left-hand side of Figure 2, the projected silhouette corresponds to the GDP growth of country $A$, while on the right-hand side we see (without projection) that in country $F$ there was no GDP growth at all over the past 200 years. The other projected silhouette shows the productivity of the six sailors on Saturday, or (in the generalised model) all countries of the world in order of their stage of development after the transmission of the innovations. Country $A$ is the most developed and country $F$ is the least advanced one. If we extend our time horizon, we can easily get the same result: only country $A$ innovates - the one which was the most advanced already at the beginning - and the rest grow as fast as they can emulate the leading edge technology.

While we stay within Jánossy's endogenous model, we are moving closer to reality if we say that - beyond the qualification of the labour force - economic development in peace times is strongly influenced by three static endowment factors and three countervailing dynamic forces. The static (hardly changeable or improvable) factors are geography, ecology, and geopolitics. The physical distance from the centres of economic growth, access to the high seas, weather conditions, the availability of exploitable natural resources (e.g. hydrocarbons), and navigable rivers all matter (Diamond 1997; Sachs 2003; Sachs 2012). Seashores and mountains and archaeological treasures inherited from the past are all valuable for the development of tourism - a high value-added industry in general. The dynamic factors are

- the inertia that slows down the market-driven changes in the quality of the labour force,

- the ambition to emulate the more advanced countries which works in the opposite direction, and

- immigration, if it helps to increase healthy rivalry in the recipient country.

I do not want to pretend that the identification of these six factors is a particularly original idea. S\&G are undoubtedly fully aware of them. However, they are all intrinsically more controversial than learning, and thus challenging to publicise in broader social circles. 


\section{Conclusion and the further direction of research}

This essay on Creating a Learning Society by Joseph Stiglitz and Bruce Greenwald shows that the term "learning" is used in the book in such a broad sense that it becomes almost meaningless as the alleged main driver of economic convergence. Another major shortcoming of S\&G is that they leave obscure to whom their policy advice is addressed: to the very poor, infant economies, the unsuccessful countries, or to every country that aspires to catch up with the world's leading economy, the United States. By using such a value-loaded, entirely positive term such as "learning", Stiglitz and Greenwald create a misleading feeling in their readers: catching up is easy. The present paper, relying on the endogenous growth theory of a lesser known late Hungarian economist, Ferenc Jánossy showed that it is not because people, for good reasons from their own perspective, resist change. Furthermore, catching up is difficult, because if your competitors are moving ahead, you have to move just as fast, just not to lose ground.

This essay was already accepted for publication when the news came that Paul Romer was awarded the 2018 Nobel Memorial Prize for laying down the foundation of the endogenous growth theory in 1990. A comparison of Romer's model with that of Jánossy should be the subject of a next study.

\section{References}

Acemoglu, D. - Robinson, J.A. (2012): Why Nations Fail: The Origins of Power, Prosperity, and Poverty. New York: Crown Business.

Arrow, K.J. (1962): The Economic Implications of Learning by Doing. The Review of Economic Studies, 29(3): 155-173. https://doi.org/10.2307/2295952

Carrol, L. (1865): Alice's Adventures in Wonderland. London: Macmillan.

Cox, S. (2017): Out of the traps. Emerging Markets Special Report, The Economist, 7 October.

Diamond, J.M. (1997): Guns, Germs, and Steel: The Fates of Human Societies. W.W. Norton \& Company.

Greenwald, B.C. - Stiglitz, J.E. (2006): Helping Infant Economies Grow: Foundations of Trade Policies for Developing Countries. American Economic Review: AEA papers and Proceedings, 96(2): 141-146. https://doi.org/10.1257/000282806777212206

Hanushek, E.A. - Woessmann, L. (2012): Do betters schools lead to more growth? Cognitive skills, economic outcomes, and causation. Journal of Economic Growth, 17(4): 267-321. https://doi.org/10.1007/s10887-012-9081-x

Holló, M. (1974): Technika és Társadalom (Technology and Society). Bp.: Kossuth Kiadó. 
Hughes, C. - Tight, M. (1995): The Myth of the Learning Society. British Journal of Education Studies, 43(3): 290-304. https://doi.org/10.1080/00071005.1995.9974038

Husén, T. (1986): The Learning Society Revisited. Oxford: Pergamon.

Hutchins, R.M. (1970): The Learning Society. Harmondsworth: Penguin.

Jánossy, F. (1969): Wiedersprüche in der Ungarischen Wirtschaftsstruktur - Wie sind sie entstanden und wie können sie überwunden werden. Acta Oeconomica, 4(4): 351-377.

Jánossy, F. (1971): The End of the Economic Miracle. Appearance and Reality in Economic Development. White Plains, N.Y.: International Arts and Science Press, Inc.

Joffe, M. (2017): Evidence and the micro-foundations of economic growth. Economics and Business Review, 3(17)(3): 52-79. https://doi.org/10.18559/ebr.2017.3.4

Jones, C.I. (2015): The facts of economic growth. NBER Working Paper Series 21142, May. https://doi.org/10.3386/w21142

Kaldor, N. (1966): Causes of the Slow Rate of Economic Growth of the United Kingdom. An Inaugural Lecture. London: Cambridge University Press.

Kornai, J. (2014): Dynamism, Rivalry and the Surplus Economy. Two Essays on the Nature of Capitalism, Oxford: OUP.

Krugman, P. (2016): When the Ridiculous is Ominous. The New York Times, 3 December. https://krugman.blogs.nytimes.com/2016/12/03/when-the-ridiculous-is-ominous/?_r=0

Lavoie, D. (1985): Rivalry and central planning (The socialist calculation debate reconsidered). Cambridge University Press.

Lewis, W.W. (2004): The Power of Productivity. Wealth, Poverty, and the Threat to Global Stability. Chicago: The University of Chicago Press. https://doi.org/10.7208/ chicago/9780226477008.001.0001

List, F. (1841): Das nationale System der politischen Ökonomie. Stuttgart/Tübingen.

McKinsey \& Company (2010): How the world's most improved school systems keep getting better. August.

Mihályi, P. (2017): Kaldor and Kornai on Economics without Equilibrium. Acta Oeconomica, 67(Special Issue): 47-66. https://doi.org/10.1556/032.2017.67.S.5

Mihályi, P. - Szelényi, I. (2017): The Role of Rents in the Transition from Socialist Redistributive Economies to Market Capitalism. Comparative Sociology, 16(1): 13-38. https://doi. org/10.1163/15691330-12341419 
Myrdal, G. (1957): Economic Theory and Underdeveloped Regions. London: Duckworth.

OECD (2000): Knowledge Management in the Learning Society. Paris: OECD Publishing.

Pigou, A. (1920): The Economics of Welfare, London: Macmillan and Co. https://www.econlib. org/library/NPDBooks/Pigou/pgEW.html?chapter_num=1\#book-reader

Piketty, T. (2014): Capital in the Twenty-first Century. Cambridge: The Belknap Press of Harvard University Press. https://doi.org/10.4159/9780674369542

Polónyi, I. (2010): A mitikus oktatás (Mythical Education). In: Kotsis, Á. - Polónyi, I. (eds): Felsőoktatási intézmények és az innováció (Higher Education Institutions and Innovation). Competitio Könyvek 11. Debreceni Egyetem - Közgazdaság- és Gazdaságtudományi Kar. 143-163.

Pritchett, L. (2006): Does learning to add up add up? The returns to schooling in aggregate data. In: Hanushek, E. - Welch, F. (eds): Handbook of the Economics of Education. Vol. 1. Elsevier. 635-695. https://doi.org/10.1016/S1574-0692(06)01011-7

Reeves, R.V. (2017): Dream Hoarders. How the American upper middle class is leaving everyone else in the dust, why that is a problem and what to do about it. Washington D.C.: Brookings Institution Press.

Rostow, W.W. (1960): The Stages of Economic Growth: A Non-Communist Manifesto. Cambridge: Cambridge University Press.

Sachs, J.D. (2003): Institutions Don't Rule: Direct Effects of Geography on Per Capita Income. NBER Working Paper No. 9490. https://doi.org/10.3386/w9490

Sachs, J.D. (2012): Government, Geography, and Growth, The True Drivers of Economic Development. Foreign Affairs, September/October.

Schön, D. (1973): Beyond the Stable State. Public and private learning in a changing society. Harmondsworth: Penguin.

Stiglitz, J.E. - Greenwald, B.C. (2014): Creating a Learning Society. A New Approach to Growth, Development, and Social Progress. New York: Columbia University Press. https:// doi.org/10.7312/columbia/9780231152143.001.0001

Stiglitz, J.E. (1987): Learning to Learn, Localized Learning and Technological Progress. In: Dasgupta, P. - Stoneman, P. (eds.): Economic Policy and Technological Performance, 125-153. Cambridge, UK: Cambridge University Press. https://doi.org/10.1017/ CBO9780511559938.007

Tarján, T.G. (2002): Jánossy's Trendline Theory in the Light of the New Growth Theory. Acta Oeconomica, 52(1): 79-104. https://doi.org/10.1556/AOecon.52.2002.1.4 
The Conference Board (2017): Total Economy Database, Output, Labour and Labour Productivity, 1950-2017, May.

Thirlwall, A.P. (2017): Nicholas Kaldor's life and insights into the applied economics of growth. Acta Oeconomica, 67(Special Issue): 11-30. https://doi.org/10.1556/032.2017.67.S.2

Van Valen, L. (1973): A New Evolutionary Law. Evolutionary Theory, 1(1): 1-30.

Veuglers, R. (2017): The Challenge of China's Rise as a Science and Technology Powerhouse. 27 August. http://www.brinknews.com/asia/the-challenge-of-chinas-rise-as-a-scienceand-technology-powerhouse/. Downloaded: 1 September 2017.

Verdoorn, P.J. (1949): Fattori che Regalano lo Sviluppo della Produttivita del Lavoro. L'Industria, No. 1. republished in English: On the Factors Determining the Growth of Labor Productivity. In: Pasinetti, L. (ed.): Italian Economic Papers. Oxford: Oxford University Press, 1993.

Vonyó, T. (2008): The Economics of Wartime Destruction and Post-War Dislocation Factor accumulation and productivity growth in West German industry between 1939 and 1950. Paper presented at the $8^{\text {th }}$ Congress of the European Historical Economics Society, Geneva, 5th of September 2008.

Williamson, J. (1990): What Washington Means by Policy Reform. In: Williamson, J. (ed.): Latin American Adjustment: How Much Has Happened? Washington, D. C.: Institute for International Economics.

Williamson, J. (2008): A Short History of the Washington Consensus. In: Serra, N. - Stiglitz, J.E. (eds.): The Washington Consensus Reconsidered - Towards a New Global Governance. Oxford: University Press.

Wright, T.P. (1936): Factors Affecting the Cost of Airplanes. Journal of the Aeronautical Sciences, 3(4): 122-128. https://doi.org/10.2514/8.155 